Bull. Mater. Sci., Vol. 3, Number 3, November 1981, pp. 271-274. O Printed in India.

\title{
Preparation of some transition metal sulphides*
}

\author{
J GOPALAKRISHNAN \\ Solid State and Structural Chemistry Unit, Indian Institute of Science, \\ Bangalore 560012 , India
}

MS received 2 April 1981

\begin{abstract}
Ternary sulphides, $\mathrm{LnMS}_{\mathrm{g}}(\mathrm{Ln}=$ rare earth metal; $\mathrm{M}=$ first row transition metal) and $\mathrm{MV}_{2} \mathrm{~S}_{4}(\mathrm{M}=\mathrm{Mg}, \mathrm{Fe}, \mathrm{Co}, \mathrm{Ni}$ and $\mathrm{Zn})$ have been prepared by the reaction of appropriate ternary metal oxides with $\mathrm{H}_{2} \mathrm{~S}$ or $\mathrm{CS}_{2} / \mathrm{N}_{2}$ vapours at elevated temperatures. Chemical analysis and $\mathrm{x}$-ray powder diffraction of the products indicate formation of single-phases with unique crystal structures in many cases.
\end{abstract}

Keywords. Transition me1al sulphides, preparation; rare earth sulphides.

\section{Introduction}

Metal sulphides constitute an important class of solids crystallizing in a variety of structures and exhibiting a wide range of physical properties (Rao and Pisharody 1976). Many of them occur naturally as minerals : pyrite $\left(\mathrm{FeS}_{2}\right)$, chalcopyrite $\left(\mathrm{CuFeS}_{2}\right)$, molybdenite $\left(\mathrm{MoS}_{2}\right)$ for example. This class of solids offers immense scope for research towards understanding the interrelationship between structure and physical properties. For this purpose, convenient and reliable methods for the preparation of authentic samples are essential.

Transition metal sulphides are generally prepared by high temperature reaction of the constituent elements in sealed evacuated tubes. When the metal sulphide is quite stable, metathetical reaction between suitable components yields the product : for example, $\mathrm{MoS}_{2}$ can be prepared by fusing $\mathrm{MoO}_{3}$ with a mixture of sulphur and $\mathrm{K}_{2} \mathrm{CO}_{3}$. The method of reacting elements in sealed tubes suffers from several disadvantages such as formation of multiphases, incomplete reaction and inhomogeneities in composition even where a single phase is obtained. Moreover, the method is not convenient for the synthesis of sulphides of rare earth metals in view of the difficulty in getting high-purity rare earth metals and their sensitivity to air and moisture.

We have developed methods for the synthesis of several ternary sulphides containing rare earth and transition metals based on the reaction of appropriate metal oxides with $\mathrm{H}_{2} \mathrm{~S}$ or $\mathrm{CS}_{2}$ vapours at elevated temperatures. Preparation of some metal sulphides using $\mathrm{H}_{2} \mathrm{~S}$ and $\mathrm{CS}_{2}$ vapour has been reported in the literature (Shafer 1972; Takahashi et al 1971; Lelieveld and Ijdo 1980).

*Communication No. 117 from the Solid State and Structural Chemistry Unit. 


\section{Experimental and Results}

2.1. Preparation of $\mathrm{LnMS}_{3}(\mathrm{Ln}=\mathrm{La}, \mathrm{Nd}, \mathrm{Gd} ; \mathrm{M}=\mathrm{V}, \mathrm{Cr}, \mathrm{Mn}, \mathrm{Fe}, \mathrm{Co}$ and $\mathrm{Ni})$. The following $\mathrm{LnMO}_{\mathrm{x}}$ oxides were prepared from high-purity binary oxides: $\mathrm{LnVO}_{4}, \mathrm{LnVO}_{3}, \mathrm{LnCrO}_{3}, \mathrm{LaMnO}_{3}, \mathrm{LaFeO}_{3}, \mathrm{LaCoO}_{3}, \mathrm{LaNiO} \mathrm{NaC}_{3}$ and $\mathrm{La}_{2} \mathrm{Cu}_{2} \mathrm{O}_{5}$. About $5 \mathrm{~g}$ of $\mathrm{LnMO}_{\mathrm{x}}$ taken in a graphite boat were placed in a alumina combustion tube held horizontally in a tubular furnace. For reaction with $\mathrm{H}_{2} \mathrm{~S}$, dry $\mathrm{H}_{2} \mathrm{~S}$ from a Kipp's apparatus was passed over the sample (3$5 \mathrm{ml} / \mathrm{min}$ ) while the furnace temperature was raised to the desired value $\left(100 \mathrm{C}-1200^{\circ} \mathrm{C}\right)$. For reaction with $\mathrm{CS}_{2}$ vapour, a stream of dry, oxygen-free, nitrogen was bubbled through $\mathrm{CS}_{2}$. Nitrogen thus saturated with $\mathrm{CS}_{2}$ was passed over the sample. Each sample was repeatedly heated with intermittent grinding until the reaction was complete (as indicated by constant weight). It generally took over $100 \mathrm{hrs}$ of total reaction time for the reaction to be complete in many cases.

Chemical analysis (table 1) showed that in all the cases excepting copper, the composition of the sulphides was $\mathrm{LnMS}_{3}$. In the case of copper, reaction $\mathrm{n}_{i}$ of $\mathrm{La}_{2} \mathrm{Cu}_{2} \mathrm{O}_{5}$ with $\mathrm{H}_{2} \mathrm{~S}$ yielded $\mathrm{LaCuS}_{2}$ as the product. X-ray powder diffraction showed that the sulphides were monophasic with unique crystal structures. Among $\mathrm{LaMS}_{3}, \mathrm{M}=\mathrm{V}$ and $\mathrm{Cr}$ sulphides are isostructural crystallizing in a monoclinic structure while $\mathrm{M}=\mathrm{Mn}, \mathrm{Fe}$, Co and $\mathrm{Ni}$ sulphides form another isostructural series having a hexagona1 structure (Murugesan et al 1981).

2.2 Preparation of $M_{\mathrm{x}} V S_{2}(\mathrm{M}=\mathrm{Mg}, \mathrm{Fe}, \mathrm{Co}, \mathrm{Ni}$ and $\mathrm{Zn} ; x=0.5$ and 0.25$)$. We have also prepared a series of metal-intercalated vanadium disulphides, $\mathrm{M}_{\mathrm{x}} \mathrm{VS}_{2}(\mathrm{M}=\mathrm{Mg}, \mathrm{Fe}, \mathrm{Co}, \mathrm{Ni}$ and $\mathrm{Zn})$, by reaction of $\mathrm{MV}_{2} \mathrm{O}_{6}$ and $\mathrm{MV}_{4} \mathrm{O}_{11}$ with $\mathrm{H}_{2} \mathrm{~S}$ at $600-1000^{\circ} \mathrm{C}$. Reaction of $\mathrm{MV}_{2} \mathrm{O}_{6}$ with $\mathrm{H}_{2} \mathrm{~S}$ gives $\mathrm{M}_{0.5} \mathrm{VS}_{2}$ while reaction of $\mathrm{MV}_{4} \mathrm{O}_{11}$ gives $\mathrm{M}_{0 \cdot 25} \mathrm{VS}_{2}$. The sulphidation reaction involves simultaneous reduction of vanadium. For instance, $\mathrm{MV}_{2} \mathrm{O}_{6}+6 \mathrm{H}_{2} \mathrm{~S} \rightarrow \mathrm{MV}_{2} \mathrm{~S}_{4}+6 \mathrm{H}_{2} \mathrm{O}+2 \mathrm{~S}$. It must be mentioned that the composition of the sulphide is sensitive to reaction temperature. The higher the temperature the lower is the sulphur content of the product in general. Thus $\mathrm{M}_{0.25} \mathrm{VS}_{2}$ phases are formed at lower temperatures than $\mathrm{M}_{0.5} \mathrm{VS}_{2}$ phases. For a given $\mathrm{M}_{\mathrm{X}} \mathrm{VS} \mathrm{S}_{2}$, iron, cobalt and nickel compounds are formed at lower temperatures while magnesium and zinc compounds require higher temperatures for their formation.

Table 1. Characterization of $\mathrm{LnMS}_{3}$.

\begin{tabular}{lccccccc}
\hline & \multicolumn{2}{c}{ Sulphur (\%) } & \multicolumn{5}{c}{ Unit cell parameters } \\
\cline { 2 - 5 } \cline { 5 - 8 } Compound & found & calculated & & $a$ & $b$ & $c$ & $\beta$ \\
& & & & $(\AA)$ & $(\AA)$ & $(\AA)$ & $(\AA)$ \\
\hline $\mathrm{LaVS}_{3}$ & 34.17 & 33.58 & & 5.985 & 16.854 & 11.158 & 89.7 \\
$\mathrm{LaCrS}_{3}$ & 33.55 & 33.45 & & 5.970 & 17.110 & 11.033 & 87.5 \\
$\mathrm{LaMnS}_{3}$ & 33.98 & 33.12 & & 10.370 & - & 5.772 & - \\
$\mathrm{LaFeS}_{3}$ & 33.33 & 33.02 & & 10.314 & - & 5.806 & - \\
$\mathrm{LaCoS}_{3}$ & 32.92 & 32.67 & & 10.318 & - & 5.776 & - \\
$\mathrm{LaNiS}_{3}$ & 32.59 & 32.68 & & 10.295 & - & 5.762 & - \\
\hline
\end{tabular}


Table 2. Characterization of $\mathrm{MV}_{2} \mathrm{~S}_{4}$.

\begin{tabular}{lccccccc}
\hline & \multicolumn{3}{c}{ Sulphur $(\%)$} & \multicolumn{5}{c}{ Unit cell parameters } \\
\cline { 2 - 3 } \cline { 6 - 8 } Compound & found & calculated & & $a$ & $b$ & $c$ & $\beta$ \\
& & & & $(\AA)$ & $(\AA)$ & $(\AA)$ & $(\AA)$ \\
\hline $\mathrm{MgV}_{2} \mathrm{~S}_{4}$ & 50.01 & $5 \mathrm{~A} \cdot 40$ & & 5.839 & 3.274 & 11.333 & 91.81 \\
$\mathrm{FeV}_{2} \mathrm{~S}_{4}$ & 45.92 & 44.84 & & 5.863 & 3.298 & 11.272 & 92.01 \\
$\mathrm{CoV}_{2} \mathrm{~S}_{4}$ & 44.16 & 4436 & & 5.828 & 3.281 & 10.925 & 92.32 \\
$\mathrm{NiV}_{2} \mathrm{~S}_{4}$ & 44.58 & 44.52 & & 5.942 & 3.279 & 11.107 & 92.20 \\
\hline
\end{tabular}

Chemical analyses show that the products are indeed $\mathrm{MV}_{2} \mathrm{~S}_{4}$ and $\mathrm{MV}_{4} \mathrm{~S}_{8}$. $\mathrm{X}$-ray diffraction data (table 2) reveal that $\mathrm{MV}_{2} \mathrm{~S}_{4}$ sulphides are isostructural with $\mathrm{V}_{3} \mathrm{~S}_{4}$ having vacancy $\cdots$ ordered NiAs-related structures (Oka et al 1978).

\section{Discussion}

The present study shows that the gas-solid reaction between $\mathrm{H}_{2} \mathrm{~S}$ or $\mathrm{CS}_{2}$ vapours and metal oxides can ke efiectively used for the synthesis of ternary metal sulphides. The method thus obviates the necessity to use elements as starting materials and this is particularly an advantage in the preparation of rare earth containing sulphides.

Although sulphidation may be thought of as a direct reaction between-the oxide and $\mathrm{H}_{2} \mathrm{~S}$ or $\mathrm{CS}_{2}$, e.g.,

$$
\begin{aligned}
& \mathrm{LaMO}_{3}+3 \mathrm{H}_{2} \mathrm{~S} \rightarrow \mathrm{LaMS}_{3}+3 \mathrm{H}_{2} \mathrm{O} \\
& \mathrm{LaMO}_{3}+3 / 2 \mathrm{CS}_{2} \rightarrow \mathrm{LaMS}_{3}+3 / 2 \mathrm{CO}_{2},
\end{aligned}
$$

dissociation of $\mathrm{H}_{2} \mathrm{~S}$ and $\mathrm{CS}_{2}$ vapour to $\mathrm{S}_{2}$ is likely to be an intermediate stcp, since it is known that $\mathrm{S}_{2}$ molecules promote formation of sulphides ( $S$ winnea and Steinfink 1980). Among the two sulphiding agents, $\mathrm{H}_{2} \mathrm{~S}$ seems to be appropriate for the synthesis of sulphides that involves simultaneous reduction of metal ions to lower oxidation states; for example, formation of $\mathrm{LaVS}_{3}$ from $\mathrm{LaVO}_{4}$ involves reduction of $\mathrm{V}^{5+}$ to $\mathrm{V}^{3+}$ :

$$
\begin{aligned}
& 2 \mathrm{H}_{2} \mathrm{~S}(\mathrm{~g}) \rightarrow 2 \mathrm{H}_{2}(\mathrm{~g})+\mathrm{S}_{2}(\mathrm{~g}) \\
& \mathrm{LaVO}_{4}+\mathrm{H}_{2}(\mathrm{~g}) \rightarrow \mathrm{LaVO}_{3}+\mathrm{H}_{2} \mathrm{O}(\mathrm{g}) \\
& \mathrm{LaVO}_{3}+3 \mathrm{H}_{2} \mathrm{~S}(\mathrm{~g}) \rightarrow \mathrm{LaVS}_{3}+3 \mathrm{H}_{2} \mathrm{O}(\mathrm{g})
\end{aligned}
$$

Similarly during the formation of $\mathrm{BaVS}_{3}$ from $\mathrm{Ba}_{2} \mathrm{~V}_{2} \mathrm{O}_{7}$, vanadium is reduced from $5+$ to $4+$ states.

With $\mathrm{CS}_{2}$ reaction, deposition of carbon was found to occur in some cases especially when the flow rate is high. 


\section{Acknowledgements}

Grateful thanks of the author are due to Professor C N R Rao for suggesting this area of work and taking keen interest in the progress. The author thanks Mr S Ramesh for help in experimental work.

\section{References}

Lelieveld R and Ijdo D J W 1980 Acta Crystallogr. B36 2223

Murugesan T, Ramesh S, Gopalakrishnan J and Rao C N R 1981 J. Solid State Chem. 38165

Oka Y, Kosuge K and Kachi S 1978 J. Solid State Chem. 2311

Rao C N R and Pisharody K P R 1976 Progr. Solid State Chem. 10207

Shafer M W 1972 Mater. Res. Bull. 7603

Swinnea J S and Steinfink H 1980 J. Chem. Ed. 57580

Takahashi T, Oka T, Yamada O and Ametani K 1971 Mater. Res. Bull. 6173 